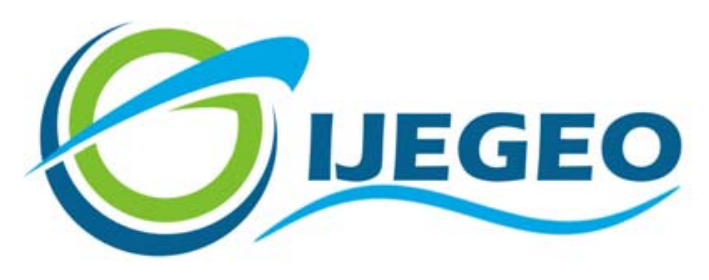

International Journal of Environment and Geoinformatics (IJEGEO) is an international, multidisciplinary, peer reviewed, open access journal.

\title{
Assessment of Tsunami-related Geohazard Assessment for Hersek Peninsula and Gulf of İzmit Coasts
}

\author{
Cem Gazioğlu
}

\section{Editors}

Prof. Dr. Cem Gazioğlu, Prof. Dr. Dursun Zafer Şeker, Prof. Dr. Ayşegül Tanık, Assoc. Prof. Dr. Şinasi Kaya

\section{Scientific Committee}

Assoc. Prof. Dr. Hasan Abdullah (BL), Assist. Prof. Dr. Alias Abdulrahman (MAL), Assist. Prof. Dr. Abdullah Aksu, (TR); Prof. Dr. Hasan Atar (TR), Prof. Dr. Lale Balas (TR), Prof. Dr. Levent Bat (TR), Assoc. Prof. Dr. Füsun Balık Şanlı (TR), Prof. Dr. Nuray Balkıs Çağlar (TR), Prof. Dr. Bülent Bayram (TR), Prof. Dr. Şükrü T. Beşiktepe (TR), Dr. Luminita Buga (RO); Prof. Dr. Z. Selmin Burak (TR), Assoc. Prof. Dr. Gürcan Büyüksalih (TR), Dr. Jadunandan Dash (UK), Assist. Prof. Dr. Volkan Demir (TR), Assoc. Prof. Dr. Hande Demirel (TR), Assoc. Prof. Dr. Nazlı Demirel (TR), Dr. Arta Dilo (NL), Prof. Dr. A. Evren Erginal (TR), Dr. Alessandra Giorgetti (IT); Assoc. Prof. Dr. Murat Gündüz (TR), Prof. Dr. Abdulaziz Güneroğlu (TR); Assoc. Prof. Dr. Kensuke Kawamura (JAPAN), Dr. Manik H. Kalubarme (INDIA); Prof. Dr. Fatmagül Kılıç (TR), Prof. Dr. Ufuk Kocabaş (TR), Prof. Dr. Hakan Kutoğlu (TR), Prof. Dr. Nebiye Musaoğlu (TR), Prof. Dr. Erhan Mutlu (TR), Assist. Prof. Dr. Hakan Öniz (TR), Assoc. Prof. Dr. Hasan Özdemir (TR), Prof. Dr. Haluk Özener (TR); Assoc. Prof. Dr. Barış Salihoğlu (TR), Prof. Dr. Elif Sertel (TR), Prof. Dr. Murat Sezgin (TR), Prof. Dr. Nüket Sivri (TR), Assoc. Prof. Dr. Uğur Şanlı (TR), Assoc. Prof. Dr. Seyfettin Taş (TR), Assoc. Prof. Dr. İ. Noyan Yılmaz (TR), Assist. Prof. Dr. Baki Yokeş (TR), Assist. Prof. Dr. Sibel Zeki (TR), Dr. Hakan Kaya (TR). 


\title{
Assessment of Tsunami-related Geohazard Assessment for Hersek Peninsula and Gulf of İzmit Coasts
}

\section{Cem Gazioğlu}

Istanbul University, Institute of Marine Sciences and Management, Department of Marine Environment, 34134 Vefa Fatih Istanbul TR

$\begin{array}{lllr}\text { Tel } & :+902124400000 & \text { Received: } & 01 \text { Nov } 2016 \\ \text { E-email } & : \text { cemga@istanbul.edu.tr } & \text { Accepted: } & 03 \text { March 2017 }\end{array}$

\begin{abstract}
Tsunamis are one of the most dreadful natural disasters; they could cause abysmal damage to all kind of lives in the hinterland within instantly. It is a major right-lateral moving fault that runs along the tectonic boundary between the Eurasian Plate to the north and the Anatolian Plate to the south. The western segment of the North Anatolian Fault splits into three main branches. The northern one of NAF is generally subdivided in several subsegments that have been the source of frequent large historical earthquakes. The Sea of Marmara coasts is located on the western extension of the NAFZ which is one of the most important active faults with strike-slip characteristics, which are not likely to generate tsunami. However, in the light of tsunami catalogs based on historical documents, it is possible to say that Sea of Marmara has tsunamigenic potential. The İstanbul shorelines, Gemlik Bay, Kapıdağ N-NE shores, Gelibolu, Hersek Peinsula and Gulf of İzmit are one of the most significant geohazards in Sea of Marmara due to the tsunami effect.
\end{abstract}

Keywords: Geohazard, Tsunami, Gulf of İzmit, Hersek Peninsula/Delta/Lagoon

\section{Introduction}

Tsunamis are one of the most dreadful natural disasters; they could cause abysmal damage to all kind of lives in the hinterland within instantly. Earthquakes, landslides, volcanic eruptions, sub-bottom slumps and even meteor impacts can disturb bodies of water so as to form tsunamis, which are also known as a tidal waves. The Sea of Marmara (hereafter SoM) coasts have been repeatedly struck by tsunamis. In geological time, it is thought that some tsunami waves develop independently of tectonic movements (Gazioğlu et al., 2005). A number of large destructive earthquakes and tsunamis have happened from ancient times to the present in coastal areas of peninsula of Anatolia (Altınok et al., 2011). The SoM coasts have been frequently struck by tsunamis with respect to other coastal areas of the Aegean, Mediterranean and Black Seas. Main sources are earthquakes and co-seismic slope failures source harmful tsunamis in shoreline and coastal zone, depending on their morphological features, bathymetry and distance from source.
According to several documents, references, etc. more than 300 earthquakes are reported to have occurred between 2100 BC and AD 1900 (Soysal et al., 1981; Soysal, 1985; Kuran and Yalçıner, 1993) at Anatolian coasts. Ninety major tsunami events have impacted the Turkish coasts in the past $3000 \mathrm{yr}$ and one-third of them occurred in the SoM. According to current investigations catastrophic tsunamis affected SoM coasts 35 times (Yalçıner, et al., 2002; Altınok et al., 2011; Kaya and Gazioğlu, 2015). (Fig 1).

\section{North Anatolian Fault Zone}

It is a major right-lateral moving fault that runs along the tectonic boundary between the Eurasian Plate to the north and the Anatolian Plate to the south. The arc shaped North Anatolian Fault Zone (hereafter NAFZ) is $1500-\mathrm{km}$ long, from eastern Anatolia to the northern Aegean region in northwestern Anatolia. The northern one of NAF is generally subdivided in several subsegments that have been the source of frequent large historical earthquakes (Ambraseys and Jackson, 2000; 
Ambraseys, 2002). The western segment of the NAF splits into three main branches (Armijo et al., 2002). The fault zone consists of a single strand for most of its length and then splits into three approximately E-W-striking strands to the east of the SoM: northern, middle and and asouthern segments. SoM is located on the western extension of the NAFZ which is one of the most important active faults with strike-slip characteristics, which are not likely to generate tsunami. However, in the light of tsunami catalogs based on historical documents, it is possible to say that SoM has tsunamigenic potential (Aytöre, et al., 2016). The historical seismicity in SoM is extremely high, especially for the northern branch of the emerged NAF (Hébert et al., 2005). Historical earthquakes have occurred along the strike-slip NAF (Erdik et al. 2004; Cagatay et al. 2012; Drab et al. 2012), which can generate only small tsunamis due to such a strike-slip fault. Therefore, historical tsunamis might have occurred because of submarine landslides (Özeren et al. 2010).

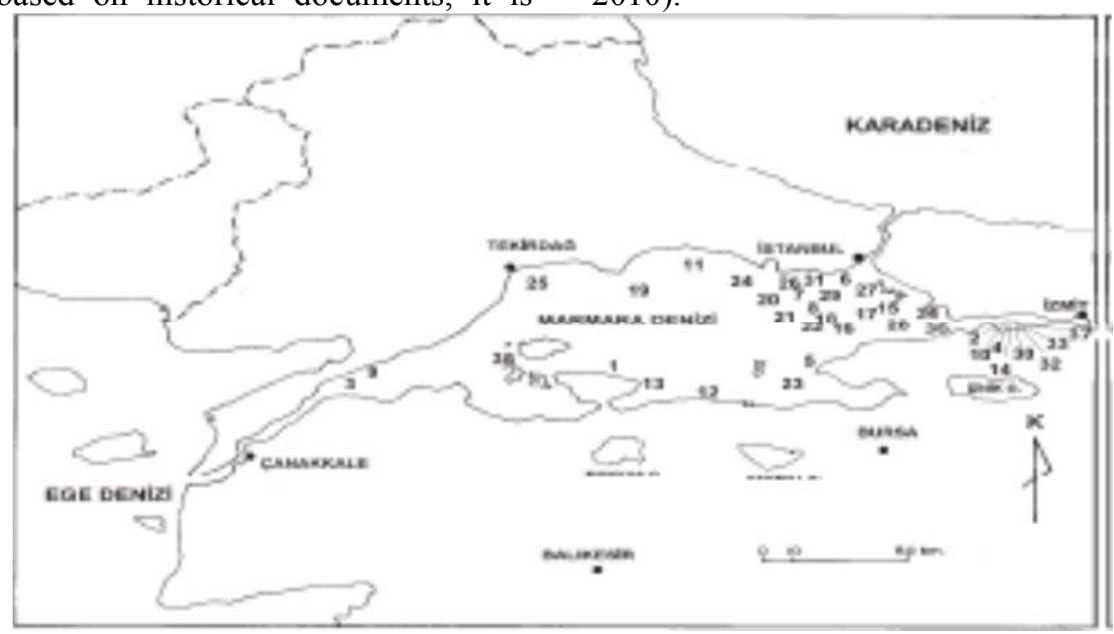

Fig 1. The tsunamis formed between the years 120-1999 in SoM (Altınok et al., 2000).

The Anatolian Block is being extruded westward within the ongoing Neotectonic regime at a rate of approximately $24 \mathrm{~mm} / \mathrm{yr}$ on the northern branch of transform NAF (Straub and Kahle, 1997) which makes the area one of the most seismically active zones of the world. The active tectonics of this region are the result of interactions between the northward moving African and Arabian plates and the relatively stable Eurasian Plate since the Early Pliocene (Bozkurt, 2001; Altınok, et al., 2011).

NAF has produced a series of 11 large earthquakes $(M s>6.7)$ during the 20th century and has ruptured most of its length during a striking westward propagating sequence between 1939 and 1999 (Soysal et al., 1981; Barka and Kadinsky-Cade, 1988; Barka, 1996; Stein et al., 1997; Straub, and Kahle, 1997; Ambraseys and Jackson, 2000). The strong Mw 7.4 earthquake that struck the Izmit area in August 1999 and followed by a secondary earthquake in November 1999, exhibited the same kind of exactly unadulterated right lateral strike slip faulting on a fault length of about $120 \mathrm{~km}$ further east (Düzce) (Barka et al., 2002; Delouis et al., 2002; Michel and Avouac, 2002). Before the 1999 earthquakes, magnitudes had already reached 7 and more in 1509, May 1766, August 1776, 1719, 1894 and 1912. It can be defined as secondary geohazard for SoM as resource tsunamis. SoM earthquakes and slope failures cause tsunamis in certain coastal areas, depending on their source features and distance to the activity center and sub-bottom morphology. Such tsunamis may attitude a significant risk to the coastal areas which are founded in the Gulf of İzmit (hereafter Goİ) and SoM coasts. The average deposition rate of muddy sediments in depressions was higher, possibly because of submarine landslides and turbidities (Altınok et al. 2001). 


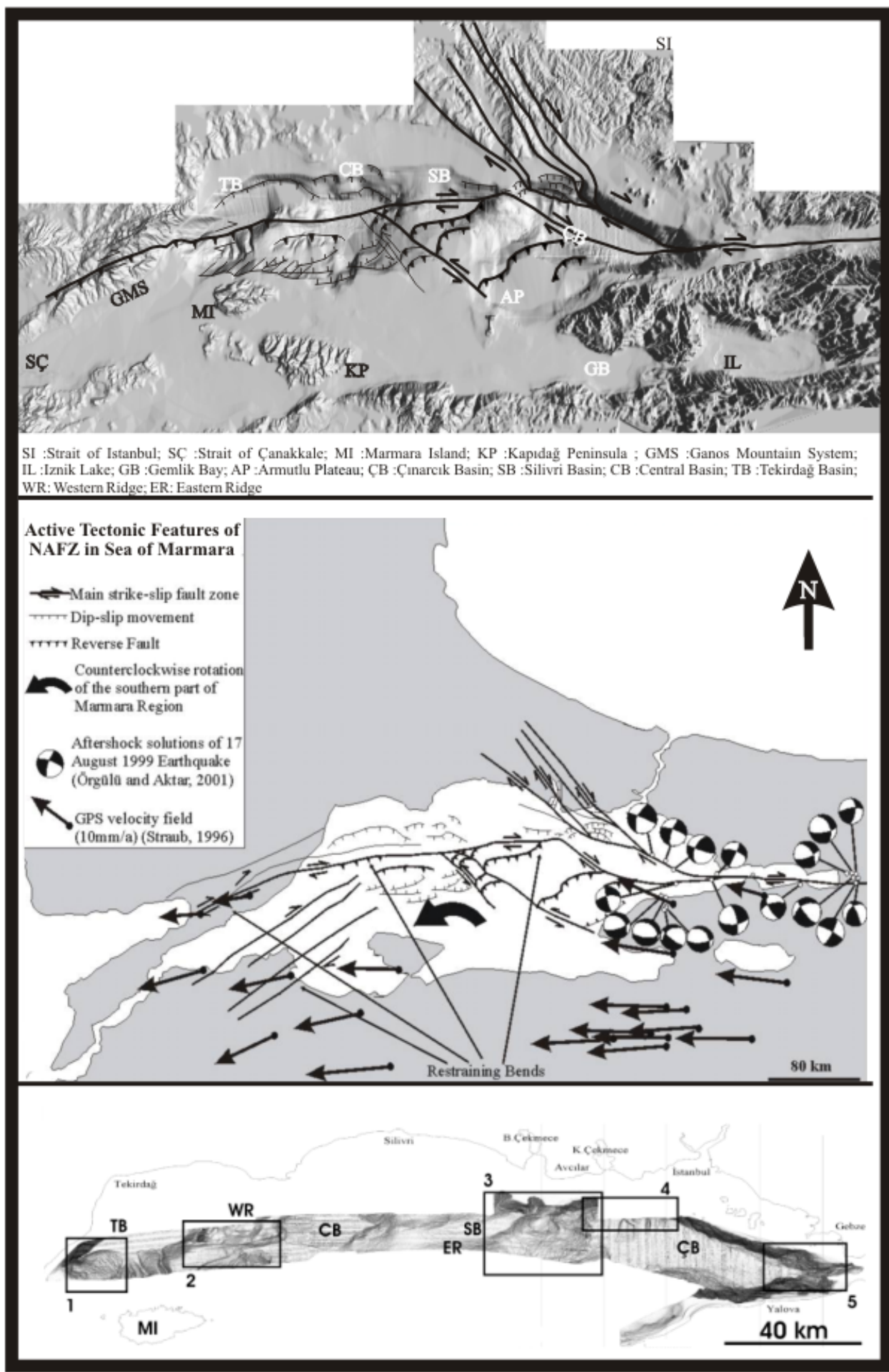

Fig. 2 a. Faults map of Marmara Sea from multi-beam bathymetric and seismic data, b. Correlation faults, earthquake solutions (Örgülü and Aktar, 2001) of Marmara Region c. Images taken from the area between the northern slope and the northern shelf with multibeam echo sounding show materials probably carried by submarine landslides (modified from Gazioğlu, 2001; Gökaşan et al., 2002; Gazioğlu et al., 2005). 
In addition, recently collected evidence during marine surveys implied that submarine mass movements or failures, such as submarine landslides and slumps, are also responsible for tsunami (Yalçıner et al. 2002). Therefore, submarine landslides are also considered when predicting possible worst-case tsunami scenarios

\section{Sea of Marmara (SoM)}

SoM is an intra-continental basin between Thrace and Anatolia, having an east-west length of about $210 \mathrm{~km}$ and a width of $75 \mathrm{~km}$. It has a relatively broad shelf $(40 \mathrm{~km})$ in the south and a narrow one $(10 \mathrm{~km})$ in the north. The shelf break is located at depth of about $110 \mathrm{~m}$. SoM is connected to the Brackish Black Sea in the northeast via the Istanbul Strait (Bosphorus) and to the saline Aegean sea in the southwest via Çanakkale Strait (Dardanelles) which known as Turkish Strait System (TSS). SoM is an $11110 \mathrm{~km}^{2}$ inland sea in northwest Anatolia located between the Black Sea and Aegean Sea (Gazioğlu 2001). It has very complex and unique sub-bottom morphology (Fig 2). The main characteristic of SoM is the east-west directed Marmara Trough, which consists of Çınarcık, Central, Silivri, and Tekirdağ basins separated by two ridges. This very complicated sub-bottom morphology of the Marmara Trough exists along the route of the northern segment of the NAFZ, which has been extensively identified since Pinar (1942) recognized the existence of a major fault along the SoM in 1942 (Ketin, 1968; Crampin and Evans, 1986; Barka and Kadinsky-Cade, 1988; Armijo et al., 1999; Hubert et al., 2000; Aksu et al., 2000; Gökaşan et al., 2001, İmren, et al., 2001; Gazioğlu, et al., 2002; Gökaşan, et al., 2002) (Fig. 2).

GoI is broadly accepted that E-W elongated basin which open by NAFZ and also is a tectonically active depositional part of it. The geology map of the surrounding area of the GoI shows that basin sediments of gulf are limited by the shoreline formed by the faults, known from the previous studies (Güven, et al., 2000; Gökaşan et al., 2001).

The faults on the coasts have developed the GoI since the basin's early opening geologically. The interpretation of the boundary faults as 66 strike-slip faults can be considered as an evidence of evolution mechanism of the GoI basins, which may be initiated as pull-apart basins. Three slopes were traced in the northward of the central basin. The middle one formed as prior central basin's slope, which is probably formed during initiation of the gulf as a pull-apart basin. Southward, some other normal faults determine the current shape of the central basin. All these faults are observed getting closer each other through subsurface indicating that these faults are connected to a buried Marmara Main Fault (Gökaşan et al., 2001; İmren, et al., 2001; Gazioğlu, et al., 2002) which cuts through the prior central basin of the gulf and has made a new morphology.

Due to inadequate current conditions, the material carried by streams may cause deltaic growths mainly along the southern coastline where the sea bottom morphology is suitable. The comprehensive investigation of the seismic sequences observed at the sub-bottom extension of the Hersek Peninsula and Delta (hereafter $\mathrm{HePe}$ and $\mathrm{HeDe}$ ) discloses intervening hydrodynamic and tectonic conditions during late Quaternary. A constricted sandy band of sea floor lies contiguous to the southern coasts of the Goİ (Fig 3).

HeDe is located within the borders of the district of Altınova, which is the easternmost of Yalova province in the Marmara Region. HeDe an altitude extending from Altınova settlement unit to the north, towards GoI in the form of a triangle. To the east of Altınova, Karamürsel (Kocaeli) and Bursa province to the south. HeDe which is the northern part of Altınova and brought to the water by Yalakdere, which takes its sources from the south, is also located in GoI in terms of geomorphological formation.

Hersek Lagoon (hereafter HeLa) situated on peninsula, surface area is approximately 1.4 $\mathrm{km}^{2}$ and very shallow $(50-60 \mathrm{~cm})$ coastal lagoon located on the southern shore of Goİ. It is the westernmost point where the NAF could be observed on land before in crosses the threshold into the SoM (Kozac1 et al., 2011). $\mathrm{HeLa}$ is separated from the adjacent SoM by a sandy coastal barrier that has been reinforced in its middle by a low-elevation material bank which is breached at several locations, allowing a continuous exchange of water between the 
HeLa and SoM. HeLa is part of HePe $\left(25 \mathrm{~km}^{2}\right)$, which comprises an area uplifted by the NAF to the north and Quaternary alluvial deposits to the south (Alpar and Güneysu, 1999; Özaksoy et al., 2010). Although Yalak River flows directly to the western HePe shores, remains of ancient stream channels that connected the river to HeLa are clearly observed. The shoreline that the delta touches the sea is covered with sandy beach cover. After the fluidity of Yalakdere's active bed has disappeared, the beach, formed by the storage of the sediments coming from the west-east coastal currents, has improved the coastal arrow and closed the lagoon lake's contact with the SoM. Under normal conditions, it laterally passes to muddy sand. However, the sea floor is covered by broad variety of material (mud to gravel) in the Hersek Pass. Peninsula was rapidly developed with the alluvium carried by the rushing Yalakdere River. This rapid sedimentation rate may also explain why the basement at the peninsula is deeper than that at the northern part of the Goİ (Alpar and Güneysu, 1999).

The being of the Pliocene conglomerates indicates that the fluvial activity lasts from late Miocene to present. The Yalakdere River and its tributaries speeded up their erosional activities beginning from late Pliocene. As a consequence of the tectonic activities which is effective from Pleistocene to present, they dig out their valleys deeper. The sediments carried by the Yalakdere River deposited into the sedimentation partly in lake and partly in stream waters or to deposits laid down under alternating or overlapping lacustrine and fluviatile conditions environment which was existed in the middle of GoI during early Pleistocene. It is estimated that the Yalakdere River continued its sedimentation activities into the fluviolacustrine environment beatween Riss-Würm interglacial periods (Alpar, et al., 1998). SoM is connected to the adjacent Mediterranean Sea and the Black Sea through TSS.

According to latest investigations (Çağatay et et al., 2015). It was cut during the glacial period when the sea level was low and the global sea level fell below the Dardanelles threshold depth. The reunion of the SoM with other oceans over the Mediterranean Sea was established by the deposition of sapropellas under oxide / dyssoxic conditions as a result of the rise of the last sea level. The latest reconnection of the SoM with the Mediterranean Sea occurred at ca. $12.0{ }^{14} \mathrm{C}$ ka BP. According to the owners of the most important sea/lake relation of SoM; during the early deglaciation stage following the last glacial maximum, the Mediterranean seawater invaded the SoM.

transitions of the SoM between the lake and sea periods is; the sea level started to rise at $-11 \mathrm{kyr}$ $\mathrm{BP}$ in the GoI causing transgression of shelves and lowstand deltas. At $-9.5 \mathrm{kyr} \mathrm{BP}$, glacial meltwater temporarily stored in the Black Sea Lake flowed toward the Aegean Sea until-7 kyr BP (Aksu et al., 1999). After the last glacial era, the water level started to rise and the Mediterranean waters began to fill SoM rapidly with the crossing of the Dardanelles Strait about 12000 years ago. Eventually the water level in the SoM started to rise rapidly and in a very short period of time the water level reached from -95 to -75 meters. With this ascension the units of the Flandrian transgression began to settle in the SoM (Aksu, et al., 2002).

Another important opinion on the geological According to several investigations (Erol, 1990; Erol and Çetin, 1995; Alpar and Güneysu, 1999; Alpar, et al., 2001) HePe continued its development during mild and wet periods (5-6 kyr BP, climatic optimum) when the TSS were completed their developments. Depending on the climatic oscillations and tectonic activities, the HeDe continues its growth with oscillating intensities from the early Holocene.

Structural evolution of GoI observed in neogene and later deposited units. All preNeogene rocks are of basic rock quality and consist of Permo-Triassic metamorphic units. The Yalova formation, Samanlıdağ formation and mid-late Pleistocene Marmara formation, which consist of members of Kilınç and Yalakdere on the foundation, constitute the basis of the geotechnical properties of the site. The accumulation of material brought by many streams downstream of the southern coast of the GoI is a resultant alluvial stripe. 

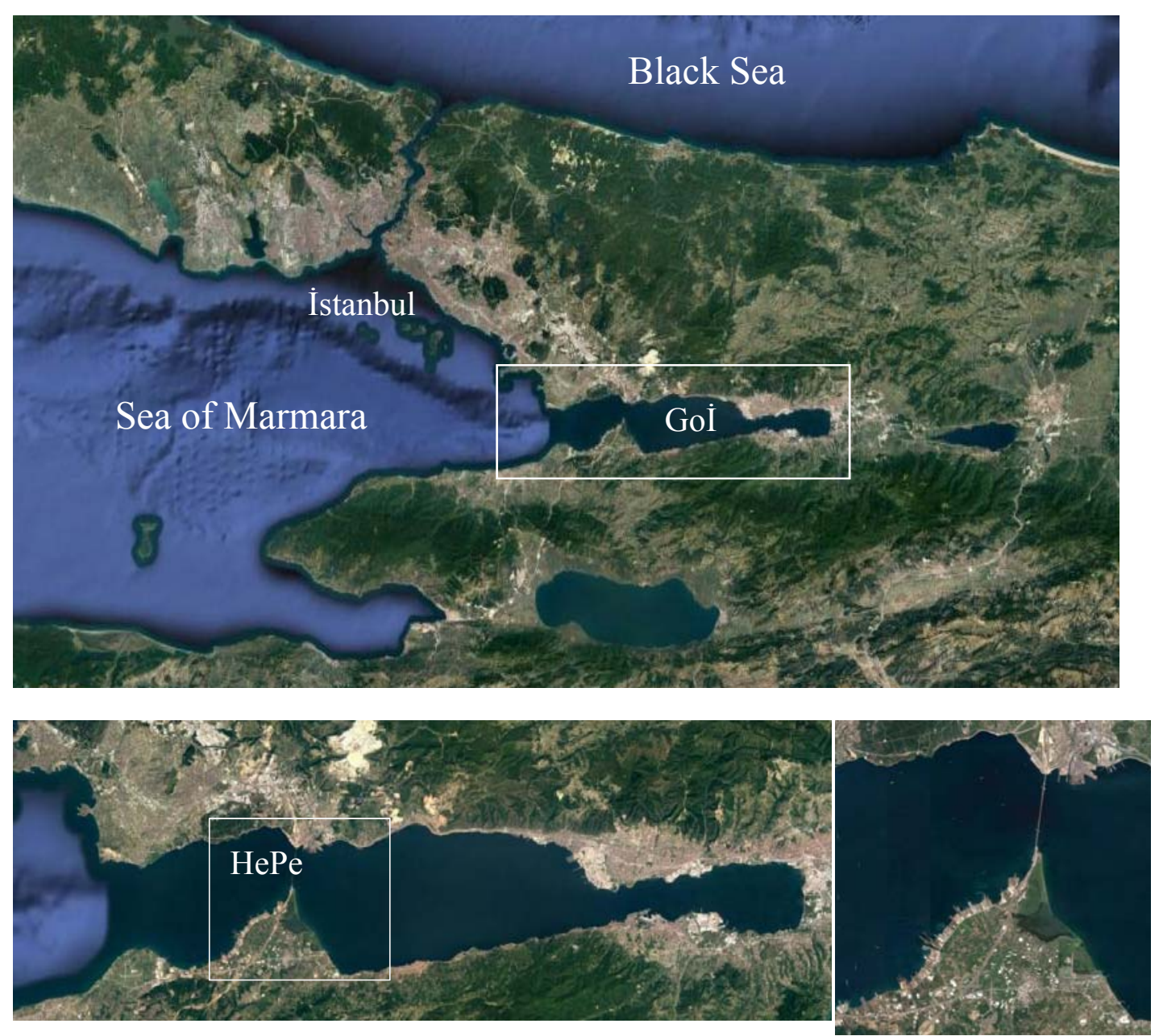

Fig 3. Sea of Marmara (SoM), Gulf of İzmit (Goİ) and Hersek Peninsula/Delta (HePe/HeDe).

From the Gölcük to the west, Karamürsel and Ereğli, this alluvial stripe narrows, filling the large areas again in Hersek and Çatal deltas. These delusions, which are formed by the material in the size of silt clay, are now wetlands or wetlands that are as swampy as the near future. In the north-western part of Altınova, sandy areas dominate the area where Yalakdere flows into the sea. In the vicinity of Hersek and Subaşı villagers, loose sand, silty sand and clay silt are dominant (Fig. 4).

HePe was subject to some restrictions that would preserve its natural characteristics until very recently, even though it included an area with significant and intensive coastal use in the coastal area of SoM. The southern boundary of the study area is formed by the Altınova settlement, while sediments of Pleistocene age marine terraces (12 -18 m, 42-48 m) (Erinç 1955; Ardel 1959; Göney, 1964; Bargu, 1997; Emre et al., 1998; Ertek et al., 2003), constitute the northern part, the HePe and GoI, the eastern Kaytazdere and the western part of the western part of the Tavşanlı settlement (Alpar, et al., 2001). Recent studies have identified numerous marine terraces at many localities on the coasts of. Absolute dating of these late Pleistocene terraces gives an average tectonic uplift rate of $0.3 \pm 0.05 \mathrm{~mm} /$ year for the last $200 \mathrm{ka}$ for the block south of the northern branch of the NAF (Yaltırak, et al., 2002).

It reflects lithologies (basalt, andesite, dolerite, gneiss, micaschist, amphibolite, sandstone, limestone, clay, marl, flysch) that the Karadere and Yağcidere branches of Yalakdere and Yağcidere branches passed over the sediments 
carried by the HeDe (Fig 4). The old valley tracks hanging on the surface of the plateau are observed in many places. Before Yalakdere developed the delta, evidence exists that there is a pigenetic narrow channel on the inland Eocene flysch between Subaşı and Kaytazdere villagers. After reaching to the north of the channel, there are marine terraces in at least 3 different altitudes, $12-18 \mathrm{~m}, 42-48 \mathrm{~m}$ and 68-74 m (Hoşgören, 1995; Alpar, et al., 2001).

The uppermost terraces are associated with a long transgression cycle after Siciliyen, and the lower terraces are associated with newer interglacial circuits. The deposits that the Late Pleistocene (Tyrrhenian) aged unit should have at $18-20 \mathrm{~m}$ or $25-30 \mathrm{~m}$ have been increased to 68-74 m with the effect of NAF. It is known that the coastal terraces of SoM have increased in control of a conflicting geological regime on their active edges in connection with the tectonic properties of the region. The locations of all the terraces on the sea level are tectonic. The subject lies in the delta towards the north in front of the marine terraces. The old bed traces belonging to Yalakdere are found from the south side of HeLa coasts.
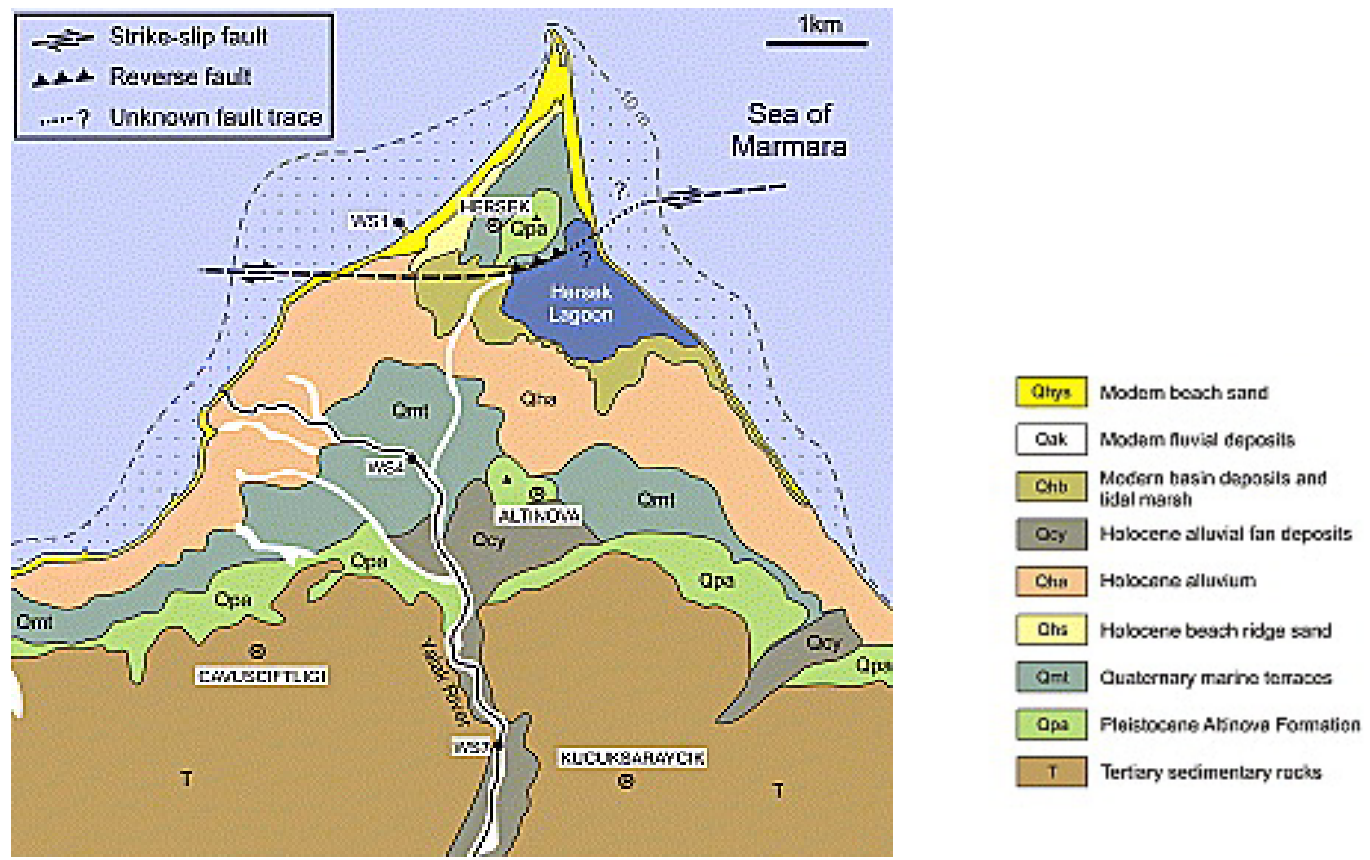

Fig.4 Map of Hersek Peninsula, based on Witter et al. (2000). The fault geometry is drawn according to Cormier et al. (2006), Özaksoy et al.(2010) and Kozac1 et al.(2011) (modified from Geological Bertrand et al., 2011).

\section{Geeohazard features of Goİ and HePe}

The youngest marine terrace was associated to the 1509 earthquake. According to Bertrand et al. (2011), HePe sedimentations related to the limitation tendency, the deposits stored in the HeLA show that the paleosismological record shows that the coastal deformation in large earthquakes is accommodated by $60-200 \mathrm{~cm}$ collapse events and shows the last fillings by protecting HeLa's statue. When the depressions were evaluated, four large depressions were found. It is estimated that the depressions belong to the earthquakes of 740,987, 1509 and 1719 years. As long as they are destructive to each other, in the wake of these major earthquakes in SoM, the deposits of the developing tsunami waves are not visible on the HePe coasts.

The primary source of current sediments in marine areas is heavy rainfall material of terrestrial origin carried by erosion. This clastic material, which is usually of a siliceous construction, develops accumulation cones in front of the mouths of the streams. The solid 
material likewise precipitates in the inner parts of the gulf. In the vicinity of the HeDe, the sea floor is covered with silt, clayey silt and clayey mud towards deeper.

GoI is also disposed to to tsunami. The 1999 İzmit earthquake, for example, caused a damaging tsunami with runups of $1-2.5 \mathrm{~m}$ in most GoI (Altınok and Ersoy, 2000; Altınok et al, 2001; Alpar et al., 2004). It was very likely caused by the combined effect of coseismic vertical deformations and local submarine slump (Gazioğlu et al., 2005) and was accompanied by coastal landslides and subsidence (Altınok et al., 2001). Plain coastal subsidence and inundation (sea) were observed (Simav et al., 2013; Direk, et al., 2012 ) within the coastal basins during the 1999 earthquake. Geotechnical and geologic site investigations were performed at several coastal sites to assess the failure mechanisms that caused the observed settling (Rathje, et al., 2004).

Tsunamis are of practical interest in risk assessment, disaster management and mitigation. Although there are numerous submarine landslides on the steep continental SoM slopes, although the NAF tectonic features limit the potential to produce tsunami. Shelf area delineated with a prominent shelf break at about $100 \mathrm{~m}$ water depth has the largest proportion $(55 \%)$ among the other morphological units (Gazioğlu et al., 2002). The northern shelf area is narrow $(5-10 \mathrm{~km}$ in width) compared to the southern shelf ( 30 $\mathrm{km}$ in width), extends to $90-100 \mathrm{~m}$ water depth, widening eastwards, and almost disappears in the west, between Mürefte and Çanakkale Strait. It extends parallel to the shoreline, widening to about $12 \mathrm{~km}$ at the confluence of Istanbul Strait and in the vicinity of the Prince Islands, and terminating in GoI in the east. The southern shelf extends to $100 \mathrm{~m}$ water depth and has a maximum width of $30 \mathrm{~km}$ between Kapıdağ and Armutlu Peninsulas, and includes Erdek, Bandırma and Gemlik Bays. The self-margins of SoM are quite erect in places. In particular, the average distance between some areas in the region between the GoI and the Büyükçekmece Lake in Northern self is $12^{\circ} \pm 1.0^{\circ} \%$ and in some places reaches $17^{\circ} \pm 1.5^{\circ}$ in some points (Gazioğlu, 2001; Gazioğlu et al., 2005; Görür and Çağatay, 2010). SoM indeed presents 70 promising situations for unstable submarine mass, with high sedimentation rates, dominated by silico-clastic deposits, drastic paleoenvironmental changes caused by global sealevel oscillations enhanced by a unusual physiography (Zitter, et al., 2012). The shelf edges have potential for submarine landslides and currents. They also developed in such a way that they could act independently of tectonism. Particularly different stratification regimes due to marine sediments overlying the sediments deposited at the time of Marmara Lake show an increasing effect on fluidity in some regions. According to Çağatay (2017) SoM slope stability has changed with the changing water level 20000 years ago and has become less stable. This has been caused primarily by the fact that the water level has dropped to the shelf limit, the sediments have accumulated more on the slopes and the sediment has become more active by changing the clay content relatively. One of the bestknown examples of these is the Tuzla Submarine Landslide complex (hereafter TSLC). These unstable slopes display creeping down slope motion component, with a direction of motion coincident with the underlying crustal stretching. The stretching of the crust probably promotes strain softening within the shallow crust and sedimentary cover and large scale deep seated gravitational slope deformation.

TSLC is a deep seated rotational failure and it was developed between the northern shelf and abyssal plain of the Çınarcık Basin. The main slide surface of the TSLC consists of two convex sub slopes distinguished by a cape of the submarine extension of Tuzla Cape (Paleozoic Rocks) which was possibly exhumed by activation of the TSLC with sliding of the covering Plio Quaternary deposits. This scenario implies that the Paleozoic basement may resist to the slidings in the area and submarine landslides can only occur in the Plio Quaternary deposits. Thus, during analyses of the submarine landslide models along the northern shelf and slope of the Çınarcık Basin, thick Plio Quaternary deposits locating on the western and the eastern sides of the TSLC were considered as potential sliding areas (Gökçeoğlu et al., 2009). TSLC will be trigged by vertical faults are analyzed from seismic profiles. The fault surfaces on the shelf 
may work as potential slip surfaces same as the unconformity surfaces. Accoriding to Özeren et al. (2010) that there is more than one submarine landslide in 127-160 ka b.p. has been proved by latest marine geological research.

Some of these are thought to have become stable since the time of the Marmara Lake in geological time, as they have maintained their presence and as a result of water level changes. TSLC is one of the very well-known submarine landslide systems located in SoM, and its mechanism suggests that it can act independently of NAF tectonism (Gazioğlu et al., 2005; Gazioğlu et al., 2014). The establishment of the shipyard zone in the HeDe western coasts, which until very recently preserved its natural characteristics, has become a center of attraction with the construction of Gazi Osman Paşa Bridge and connection roads as part of the İstanbul İzmir highway. The most important of the active tectonic features of the region is the presence of NAF and the other is the existence of the TSLC located in the North West of the HeDe. The presence of high angle continental slopes in SoM and tsunami potentials have been investigated by various researchers who mostly believed that landslides can be much more tsunamigenic than earthquakes and most of them have destructive capacity. Prove by various researchers that there are traces of many tsunami deposits of the past dated along the southern GoI shores (Erinç, 1955; Göney, 1964; Soysal, 1985; Bargu, 1997; Gazioğlu et al.,2005; Gazioğlu, et al., 2016).

The high-angle continental slopes of the SoM can produce submarine landslides and slumps, which may trigger tsunamis. Tsunami was also seen in SoM during previous earthquakes. It is higher than all other high-angle continental slopes with potential to produce tsunami, independent of tsunami tectonic activity, as the submarine landslides developed in different directions in the Tuzla area openings are in the past (Gazioğlu, et al, 2005). TSLC slope failure originates in water depth about $700 \mathrm{~m}$, with $17^{\circ}$ $\pm 1.5^{\circ}$ gradients and terminates between 200 and $1140-\mathrm{m}$ water depth. It has $50 \mathrm{~m}$ thick sediments cutting the slope of the Çinarcık Basin. TSLC is associated with a particular scar directly up gradient. Its amphitheater shaped steep upslope region (headscarp) is integrated with the shelf edge. A possible mudflow is also observed in the entrance of GoI on the course of the new rupture of the NAFZ (Gazioğlu et al., 2005; Görür and Cağatay, 2010). TSLC was evaluated by Özeren et al. (2010) that proved to be 17000 years old. It is estimated that the sea level is approximately 90 meters lower than the present (Erol, 1990). Among the TSLC scenarios, the most critical and possible ones have surface areas of $20-43 \mathrm{~km}^{2}$ and $14-33$ $\mathrm{km}^{2}$ for the western and eastern ones, the volumes were calculated as $2-4 \mathrm{~km}^{3}$ and $0.5-$ $1.5 \mathrm{~km}^{3}$, respectively.

The Tsunami will have destructive effects, especially on the $\mathrm{HePe}$ and all GoI coasts, which will cause TSLC all over, or about 17 000 years ago, the last active southeastern extension. Especially in Goí, which has a narrow channel identity, the waves between the opposite shores will increase the destructiveness of the Tsunami wave. In the tsunami wave, the wave front at the front is propagated in the horizontal plane at different frequencies and amplitudes. For this reason, the wave that follows the wave in the front is followed by a wave of waves. In places close to the shore, these wave strings interact with the wave that is reflected or broken because of effects such as coastal bathymetry and indentation in such as GoI which is narrow bay. In 1999 (İzmit Earthquake), the wave of the movement of the earthquake that occurred in GoI, was the last tsunami in the SoM. Postevent field surveys and interview of eyewitnesses conducted soon after the tsunami occurrence by several teams enabled to determine the coastal areas of major wave impact and to quantify the run-up heights and the sea penetration lengths in all the affected places. The tsunami was observed soon after the main shock. Almost in all places the tsunami was seen to cause the sea to withdraw first and then to overcome the usual shoreline and inundate land. The observed tsunami runup heights were modest and non-catastrophic. In some places it was strong enough to carry boats and vessels on land (Tinti, et al., 2006).

Though the views that tsunami did not form priorities were raised, tsunami findings were found in evaluations made at different observation sites. . 

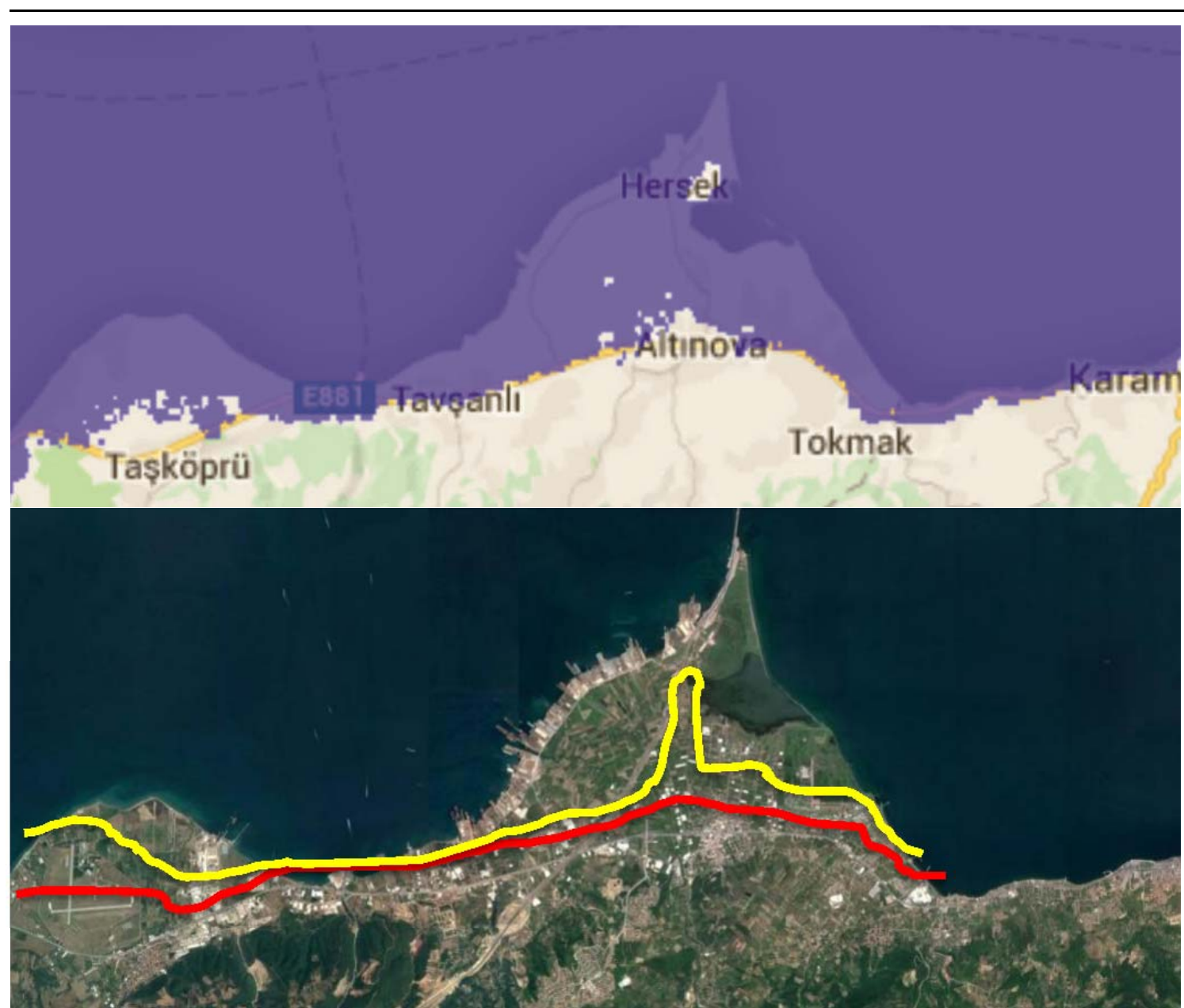

Fig. 5. A. According to the expectation of the highest tsunami wave produced from different models, the coastal regions where the tsunami wave will be effective. B.Max. and Min. inundation limits of HePe (Abal1, 2005). 
The wave motion, developed by the withdrawal of both sides of the GoÍ, reached climbing heights of 1 to 2.5 meters in the northern and southern sections. Although the tsunami waves are not larger than predicted by the models ( $\max .5 .5 \mathrm{~m}$.) expectation, it is observed that the effect of the tsunami wave besides the destruction of the earthquake is negligible, although it is not thought to cause any effective damage on the coast. Examination of different tsunami models for the SoM.

The maximum and minimum inundation lines produced by Abalı (2005) based on possible worst-case tsunami scenarios are given in figure 5. If the slope of the landscape is low and the gravitational forces are effective, the landslide will move at low speeds. The fact that the slope is large and the presence of weak particles in the inner lining of the material from which the landslide is formed allow the landslide to move at higher speeds. It is not possible for the landslide to reach great speeds due to the friction force present in the fluid. But during the earthquake, the swelling of the surface in this region may also cause landslides, in which case the speeds can reach very high values. In spite of this, some regions have caused tsunami-related damage which can be considered important. The period of the tsunami wave is less than 1 minute. Many submarine landslides (approximately 90\%) are $100 \mathrm{~km}^{2}$ small and develop in most oceans. For this reason, many submarine slip movements occur without being recorded. However, a submarine, which is located just north of the $\mathrm{NAF}$, one of the world's most active fault lines on the coast of an inland sea, such as TSLC, and very close to the shoreline and acted independently from active tectonics most recently about 17000 years ago submarine landslides can lead to disasters.

TSLC is the largest candidate for submarine landslide as a product of NAF tectonics in the region or will develop independently. According to studies (Alpar et al., 2003; Hébert et al., 2005; Kılınç, 2008; Aytöre, 2016; Gazioğlu et al., 2016) that modeled the effects of landslide, the tsunami wave from TSLC originating from the western coasts of the HePe will rise in the narrow channel with waves moving into the GoI.

\section{Conclusion}

Even though it is often possible to define areas prone to sliding, they are not able to predict hazardous locations and the potential landslide dimensions and evolution. Depending on the triggering of the masses involved, there is a vast diversity in possible processes and dynamics including, for example, release mechanisms understanding of earthquakes features, which is the main obstacle for earthquake prediction, mixing with water, landslide substages. For this reason, the features of potential seaside landslides with timetriggered records must be characterized by advanced research techniques. Depending on their characteristics, the tsunami models should be developed to assess which coastal risks they may create.

Although SoM is geologically in an inland sea category, the features of its self-esteem include all the processes that take place in the deep oceans, with the steeps and deep bases of the continental slopes. In this context, the NAFZ activity in the region, which should be effective on the shaping of the coasts and not have submarine landslide tsunamigenic potential as a feature, may trigger submarine landslides, which are considered to be geologically active, on the steep slopes of selves, leading to the development of a tsunami.

Strike-slip ground movements do not ordinarily generate tsunamis, like NAF. Some local tsunamis may be generated at the ends, the bending parts or the step-over regions of strikeslip faults. Expected earthquake(s) occurring in SoM has a direct tsunamigenic potential and, furthermore, will trigger sub-bottom masses (landslides or slumps), with supplementary possibility to produce tsunamis. Submarine landslides that can develop independently of NAFZ tectonism can be destructive effects for SoM, the tsunami wave that can eventually hit shores. In particular, residential and industrial facilities located along the Goİ coast, which have a morphologically relatively shallow and narrow canal structure, are required to reexamine their risk assessments according to the foreseen largest tsunami wave. 
The fact that the evidence of tsunami waves that may have formed due to the effect of the greatest earthquakes (the earthquakes of 740 , 987, 1509 and 1719) in SoM is not in the HePE shores is a geological matter that needs to be questioned in itself. Even within very near geological time, we are assessed by the fact that the evidence is not available because the HePe shores are shaped by interconnected and independent forces.

It is a scientific fact that the HeDe, which has low coastal characteristics due to its morphological characteristics, and the Lagoon on it and all the coasts are at great risk under the danger of tsunami. Until recent times, the HePE coasts, which has a untrodden_and low density settlement, is the geographical region that will most experience the effects of a landslide that can develop on TSLC and others tsunamis which are belong to SoM. In all of the west coast that may occur in massive shipyard located it has obviously affected all tsunamis. However, the geographical and industrial regions where TSLC will most effect are Tuzla and Yalova shipyard regions. Since the contributions of industrial plants to the country's economy are important, it is a priority to take measures that include coastal engineering issues for the region. For the development of such coastal engineering structures it is necessary to calculate a general time between landslide velocities and times of reaching the spots determined by the submarine landslides. Time to reach the shore for potential landslides should be calculated by examining the times of tsunami waves reaching the determined points on the shore. It is very important for the early warning systems of these calculations. The arrival of the tsunami waves from the formation of tsunami waves in the interior and small seas like the SoM varies between 5-15 minutes, although it does not have different results in different models. This short period of time has great importance in reducing the vulnerability of critical industrial facilities for people living in the coastal zone. The protection of the public can be achieved by the secondary destructive effects that the Tsunami coup, which can develop as a primary disaster on this site, can create.

\section{Acknowledgements}

This study was supported by Scientific Research Projects Coordination Unit of Istanbul University, Project numbers 18451.

\section{References}

Abalı, H. (2005). Tsunami danger evaluation of Marmara sea coasts, Univerity of Istanbul, Institute of Marine Sciences and Management, Department of Marine Environment MSc. Thesis, 96p.

Aksu A.E., Hiscott, R.N. and Yaşar, D. (1999). Oscillating Quaternary water levels of the Marmara Sea and vigorous outflow into the Aegean Sea from the Marmara Sea Black Sea Drainage Corridor, Mar. Geol. 153,275302.

Aksu, A.E., Calon, T.J. and Hiscott, R.N. (2000). Anatomy of the North Anatolian Fault Zone in the Marmara Sea, western Turkey: extensional basins above a continental transform, GSA Today, 10(6), 3-7.

Aksu, A.E., Hiscott, RN., Kaminski, MA., Mudie, PJ., Gillespie, H., Abrajano, T. and Yaşar, D. (2002). Last Glacial-Holocene Paleoceanography of the Black Sea and Marmara Sea: Stable İsotopic, Foraminiferal and Coccolith Evidence, Mar. Geol. 190 (1- 2),119-149.

Alpar, B. and Güneysu, AC. (1999): Evolution of the Hersek Delta (İzmit Bay), Turk. J. Mar. Sci., 5, 57-74.

Alpar, B., Altınok, Y., Gazioğlu, C. and Yücel, ZY. (2003). Tsunami hazard assessment in Istanbul, Turk. J. Mar. Sci., 9(1), 3-29.

Alpar, B., Erel, L., Gazioğlu, C., Gökaşan, E., Adatepe, FM., Demirel, S. and Algan, O. (1998). Plio-Quaternary evolution of the Enez Delta, NE Aegean Sea. Turkish J. Marine Sciences Vol. 4(1-2), 11-28.

Alpar, B., Gazioğlu, C., Altınok, Y., Yücel, ZY. and Dengiz, Ş. (2004). Tsunami hazard assessment in Istanbul using by high resolution satellite data (IKONOS) and DTM. XXth Congress of the ISPRS, Istanbul, 2004.

Alpar, B., Yüksel, Y., Doğan, E., Gazioğlu, C., Çevik, E. and Altınok, Y. (2001). An estimate of detailed depth soundings in Izmit Bay before and after 17 August 1999 
earthquake, Turkish Journal of Marine Sciences, 7(1), 3-18.

Altınok, Y. and Ersoy, Ş. (2000). Tsunamis observed on and near the Turkish Coast, Nat. Hazards, 21,185-205.

Altınok, Y., Alpar, B., Özer, N. and Aykurt, H. (2011). Revision of the tsunami catalogue affecting turkish coasts and surrounding regions, Nat Hazards Earth Syst Sci. Vol.11, 273-291.

Altınok, Y., Ersoy, Ş., Yalçıner, A.C., Alpar, B. and Kuran, U. (2001). Historical tsunamis in the Sea of Marmara. Proceedings of the International Tsunami Symposium 2001, August 7-10 2001, Seattle, WA: 527-534.

Altınok, Y., Tinti, S., Alpar, B., Yalçıner, AC., Ersoy, Ş., Bortolucci, E. and Armigliato, A. (2001). The tsunami of August 17, 1999 in İzmit Bay, Turkey, Nat. Hazards, 24, 133146.

Altınok, Y., Yalçıner, A.C., Alpar, B. ve Ersoy, Ş. (2000). Tarihsel Veriler Işı̆̆ında Marmara Denizi'nde Depreşim Dalgaları (Tsunamiler), III. Ulusal Kıyı Mühendislii Sempozyumu, Çanakkale, Türkiye, 5-7 Ekim.

Ambraseys, NN. and Jackson, JA. (2000): Seismicity of the Sea of Marmara (Turkey) since 1500 Geophys. J. Int., 141:F1-F6.

Ambraseys, NN. (2002). The seismic activity of the Marmara Sea region over the last 2000 years, Bull. Seismol. Soc. Am., 92(1): 1-18.

Ardel, A. (1959). İzmit Körfezi'nden İznik Gölüne Morfolojik Müşahadeler, İstanbul Üniversitesi Coğrafya Enstitüsü Dergisi, Sayı 10, 145-151.

Armijo, R., Meyer, B., Navarro, S., King, G. and Barka, AA. (2002), Assymetric slip partitioning in the Sea of Marmara pullapart: A clue to propagation processes of the North Anatolian Fault? Terra Nova, 14, 80-86.

Armijo, R., Meyer, B., Hubert, A. and Barka, AA. (1999). Westward propagation of the North Anatolian Fault into the northern Aegean: timing and kinematics. Geology, 27, 267-270.-

Aytöre, B., Yalçıner, AC., Zaytsev, A., Çankaya, ZC. and Süzen, ML. (2016). Assessment of tsunami resilience of Haydarpaşa Port in the Sea of Marmara by high-resolution numerical modeling. Earth, Planets and Space (2016) 68, 139.
Bargu, S. (1997). İzmit Körfezindeki Pleistosen Taraçaları ve Tektonik Özellikler, İstanbul. Üniv. Müh. Fak. Yerbilimleri Dergisi, Sayı 10,1-33.

Barka, AA. (1996). Slip distribution along the North Anatolian Fault associated with the large earthquakes of the period 1939 to 1967 Bull. Seismol. Soc. Am., 86, 1238 1254.

Barka, AA. and Kadinsky-Cade, K. (1988). Strike-slip fault geometry in Turkey and its influence on earthquake activity. Tectonics, 7, 663-684.

Barka, AA., Akyüz, HS., Altunel, E., Sunal, G., Çakır, Z., Dikbaş, A., Yerli, B., Armijo, R., Meyer, B., Chabalier, J.B.de., Rockwell, T., Dolan, JR., Hartleb, R., Dawson, T., Christofferson, S., Tucker, A., Fumal, T., Langridge, R., Stenner, H., Lettis, W., Bachhuber, J. and Page, W. (2002): The surface rupture and slip distribution of the 17 August 1999 Izmit earthquake (M 7.4), North Anatolian Fault Bull. Seismol. Soc. Am., 92 (1), 43-60.

Bertrand, S., Doner, L., Ön, S.A., Sancar, Ü., Schudack, U., Mischke, S., Çağatay, M.N. and Leroy, S. A. G., (2011). Sedimentary record of coseismic subsidence in Hersek coastal lagoon (Izmit Bay, Turkey) and the late Holocene activity of the North Anatolian Fault, Geochemistry, Geophysics, Geosystems An AGU Journal. Vol.12(6), 117.

Bozkurt, E. (2001): Neotectonics of Turkey - a synthesis, Geodinamica Acta, 14(1-3), 330.

Çağatay, M.N. (2017). Marmara marine geological surveys and their important results, 30 ${ }^{\text {th }}$ March 2017 IU IMSM conference, Prof. Dr. Sırrı Erinç Seminar Hall

Çağatay, M.N., Wulf, S., Sancar, Ü., Özmaral, A., Vidal, L., Henry, P., Appelt, O. and Gasperini, L. (2015). The tephra record from the Sea of Marmara for the last ca. $70 \mathrm{ka}$ and its palaeoceanographic implications. Marine Geology, Volume 361:96-110.

Cağatay, MN., Erel, L., Bellucci, L. G., Polonia, A., Gasperini, L., Eris, K. K., Sancar, Ü., Biltekin, D., Uçarkuş, G., Ülgen, UB. And Damc1, E. (2012). Sedimentary earthquake records in the Izmit 
Gulf, Sea of Marmara, Turkey. Sedimentary Geology, 282, 347-359.

Cormier, MH., Seeber, L., McHugh, C.M.G. Polonia, A., Cağatay, N.M., Emre, O., Gasperini, L., Görür, N., Bortoluzzi, G., Bonatti, E., Ryan, WBF. and Newman, KR. (2006). The North Anatolian fault in the Gulf of Izmit (Turkey): Rapid vertical motion in response to minor bends of a nonvertical continental transform, J. Geophys. Res., 111: 1-25.

Crampin, S. and Evans, R. (1986). Neotectonics of the Marmara Sea region of Turkey, Journal Geological Society, 143: 343-348.

Delouis, B., Giardini, D., Lundgren, P. and Salichon, J. (2002): Joint inversion of InSAR, GPS, teleseismic, and strongmotion data for the spatial and temporal distribution of earthquake slip: application to the 1999 Izmit mainshock Bull. Seismol. Soc. Am., 92 (1): 278-299.

Direk, Ş., Şeker, DZ., Musaoğlu, N . and Gazioğlu, C. (2012). Monitoring and Management of Coastal Zones Which are Under Flooding Risk with Remote Sensing and GIS, AGU, Fall Meeting 2012. 1596.

Drab, L., Ferrari, H. A., Schmidt, S. and Martinez, L. (2012). The earthquake sedimentary record in the western part of the Sea of Marmara, Turkey. Natural Hazards and Earth System Sciences., 12, 1235-1254.

Emre, Ö., Erkal, T., Tchepalyga, A., Kazanc1, N., Keçer, M. and Ünay, E. (1998). Neogene-Quaternary Evolution of The Eastern Marmara Region, Northwest Turkey, Mineral Res. Expl. Bull., 120: 119145.

Erdik, M., Demircioglu, M., Sesetyan, K., Durukal, E. and Siyahi, B. (2004). Earthquake hazard in Marmara region, Turkey. Soil Dynamics and Earthquake Engineering, 24, 605-631.

Erinç, S. (1955). Yalova Civarında Bahri Pleistosen Depoları ve Taraçaları, Türk Coğrafya Dergisi, Sayı 15-16: 188-190.

Erol, 0. (1990). Impacts of sea level rise on Turkey. Changing Climate and the Coast, Volume 2, (ed: James G. Titus): 183-200.

Erol, 0. and Çetin, 0. (1995). Marmara Denizinin Ge9 Miyosen-Holosen'deki evrimi. izmit Korfezi Kuvaterner istifi (ed: E. Meriç): 313-342.
Ertek, T.A., Yıldırım, C., Güneysu, C., Sakınç, M and Yaltırak, C. (2003). The Marine Terraces Correlation on The Sea Of Marmara Coasts (Turkey), Suppl. Geogr. Fz:L Dinam. Quat. VI:55-58.

Gazioğlu, C. (2001). Investigation of morphology of Marmara Sea bottom and surrounding area with Geomatic (in Turkish). Istanbul University, Institute of Marine Sciences and Management, Ph.D. thesis, 97p.

Gazioğlu, C., Akkaya, M.A., Baltaoğlu, S. and Burrak, S.Z. (2016). ICZM and the Sea of Marmara: The İstanbul Case. The Sea of Marmara: Marine Biodivesity, Fisheries, Conservations and Governanace (Editors: Özsoy, E., Çağatay, M.N., Balkıs, N., Balkıs Çağlar, N., Öztürk, B.): 935-957.

Gazioğlu, C., Alpar, B., Yücel, Z. Y., Müftüoğlu, A. E., Güneysu, C., Ertek, T. A., Demir, V. and Kaya, H. (2014). Morphologic features of Kapıdağ Peninsula and its coasts (NW-Turkey) using by remote sensing and DTM. International Journal of Environment and Geoinformatics, 1(1), 4863.

Gazioğlu, C., Gökaşan, E., Algan, O. Yücel, Z. Y., Tok, B. and Doğan, E., (2002). Morphologic features of the Marmara Sea from multi-beam data, Mar. Geol., 190(12): 397-420.

Gazioğlu, C., Yücel, Z. Y. and Doğan, E. (2005). Morphological features of major submarine landslides of Marmara Sea using multibean data. Journal of Coastal Research, 21(4), 664-673.

Gökaşan, E., Gazioğlu, C., Alpar, B., Yücel, ZY., Ersoy, Ş., Gündoğdu, O., Yaltırak, C. and Tok, B. (2002) Evidence of NW extension of the North Anatolian fault zone in the Marmara Sea: a new interpretation of the Marmara Sea (Izmit) earthquake on 17 August 1999. Geo Mar Lett 21:183-199.

Gökaşan, E.; Alpar, B.; Gazioğlu, C.; Yücel Z.Y.; Tok, B.; Doğan, E. and Güneysu, C. (2001). Active tectonics of the İzmit Gulf (NE Marmara Sea): from high resolution seismic and multi-beam bathymetry data. Marine Geology, 175/1-4, 271-294.

Gökçeoğlu, C., Tunusluoğlu, MC., Görüm, T., Tur, H., Gökaşan, E., Tekkeli, AB., Batuk, F. and Alp, H. (2009). Description of dynamics of the Tuzla Landslide and its implications for further landslides in the 
northern slope and shelf of the Çınarcık Basin (Marmara Sea, Turkey), Engineering Geology, Vol. 106 (3-4): 133-153.

Göney, S. (1964). Karamürsel Civarında Pleistosen'e Ait Bazı Eski Kıyı İzleri, İÜ Coğrafya Enstitüsü Dergisi, Sayı 14: 20002008.

Görür, N. and Çağatay, N. (2010). Geohazards rooted from the northern margin of the Sea of Marmara since the late Pleistocene: a review of recent results, Nat. Hazards, 54(2): 83-603.

Güven, KC., Sur, Hİ., Okuş, E., Yüksek, A., Uysal, A., Balkıs, N., Kıratlı, N., Ünlü,SV., Altıok, H., Taş, S., Aslan, A., Yıılmaz, İN., Müftüoğlu, AE., Gazioğlu, C. and Cebeci, M. (2000). Oceanography of the Izmit Bay Following 1999 Earthquake, Turkish Ministry of Environment Report.

Hébert H, Schindelé F, Altınok Y, Alpar B. and Gazioğlu, C. (2005) Tsunami hazard in the Marmara Sea (Turkey): a numerical approach to discuss active faulting and impact on the istanbul coastal areas. Mar Geol 215(1-2):23-43.

Hoşgören, M.Y. (1995). İzmit Körfezi havzasının jeomorfolojisi, İzmit Körfezi Kuvaterner İstifi, (ed: E. Meriç): 27-43.

Hubert-Ferrari, A., Barka, A.A., Jacques, E., Nalbant, S., Meyer, B., Armijo, R., Tapponnier, P. and King, G, (2000). Seismic hazard in the Sea of Marmara following the Izmit Earthquake, Nature, 404: 269-273.

İmren, C., Le Pichon, X., Rangin, C., Demirbağ, E., Ecevitoğlu, B. and Görür, N. (2001). The North Anatolian Fault within the Sea of Marmara a new evaluation based on multichannel seismic and multibeam data, Earth Planet. Sci. Lett., 186 :143-158.

Kaya, H and Gazioğlu, C. (2015). Real Estate Development at Landslides. International Journal of Environment and Geoinformatics, Vol 2(1):62-71.

Ketin, İ. (1968). Relations between general tectonic features and the main earthquake regions in Turkey. MTA Bulletin, 71, 129 134.

Kılınç, İ. (2008). Marmara Denizi’nde Meydana Gelebilecek Bir Denizalti Heyelaninin İstanbul Kıyılarına Etkileri, İTÜ, Institute of Science, PhD Thesis, 120p.
Kozacı, Ö., Altunel, E., Lindvall, S., Brankman, C. and Lettis, W. (2011). The North Anatolian Fault on Hersek Peninsula, Turkey: Its geometry and implications on the 1999 Izmit earthquake rupture propagation, Turkish J. Earth Sci. Vol.20: 359-378.

Kuran, U. and Yalçıner, A. C. (1993). Crack propogations earthquakes and tsunamis in the vicinity of Anatolia, in: Fifteenth International Tsunami Symposium, 1991, Tsunamis in the World, edited by: Tinti, S., Kluwer Academic Publishers, Holland, 159-175.

Michel, R. and Avouac, J.P. (2002): Deformation due to the 17 August 1999 Izmit, Turkey, earthquake measured from SPOT images J. Geophys. Res., 107 (B4): 2062.

Örgülü, G. and Aktar, M., 2001, Regional moment tensor inversion for strong aftershocks of the August 17, 1999, İzmit Earthquake $(\mathrm{Mw}=7.4)$, Geophys. Res. Lett., Vol 28, No 2, 371-374.

Özaksoy, V., Emre, Ö., Yıldırım. C., Doğan, A., Özalp, S. and Tokay, F. (2010). Sedimentary record of late Holocene seismicity and uplift of Hersek restraining bend along the North Anatolian Fault in the Gulf of Izmit, Tectonophysics, 487:33-45.

Özeren, M. S., Çağatay, M. N., Postacioğlu, N., Şengör, , A. M. C., Görür, N. and Eriş, K. (2010): Mathematical modelling of a potential " tsunami associated with a late glacial submarine landslide in the Sea of Marmara, Geo-Mar Lett., 30: 523-539.

Pinar, N. (1942). Geologique et meteorologique sismiques du basin de la mer de Marmara, İÜ. Fen Fak. Mecm., Series A, Cilt VII(3/ 4), 121, 182.

Rathje, E., Karatas, I., Wright, Ş. and Bachhuber, J. (2004), Coastal failures during the 1999 Kocaeli earthquake in Turkey, Soil. Dyn. Earthquake Eng. 24 (910): 699-712.

Simav Ö, Şeker DZ. and Gazioğlu C (2013) Coastal inundation due to sea level rise and extreme sea state and its potential impacts: Çukurova Delta case. Turkish J Earth Sci. 22:671-680.

Soysal, H. (1985): Tsunami (deniz taşması) ve Türkiye kıyılarını etkileyen tsunamiler, IU Bull. Mar. Sci. Geogr., 2: 59-67. 
Soysal, H., Sipahioğlu, S., Kolçak, D., Altınok, Y. (1981). Türkiye ve Çevresinin Tarihsel Deprem Kataloğu (MO 2100-MS 1900), TUBITAK project Tbag 341. İstanbul.

Stein, R.S., Barka, A.A. and Dieterich, J.H. (1997). Progressive failure on the North Anatolian Fault since 1939 by earthquake stress triggering Geophys. J. Int., 128 (1997): 594-604.

Straub, C. and Kahle, H.G. (1997). Recent crustal deformation and strain accumulation in the Marmara Sea region, NW Anatolia, inferred from repeated GPS measurements. In: Schindler, C., Pfister, M. (Eds.), Active Tectonics of Northwestern Anatolia-The Marmara Poly-Project. VdF Hochschulverlag AG der ETH, Zürich: 417-447.

Tinti, S., Armigliato, A., Manucci, A., Pagnoni, G., Zaniboni, F. Yalçıner, AC. and Y. Altınok. (2006). The generating mechanisms of the August 17, 1999 Izmit bay (Turkey) tsunami: Regional (tectonic) and local (mass instabilities) causes, Mar. Geol., 225(1-4): 311-330.

Witter, R., Lettis, W., Bachhuber, J., Barka, AA. Evren, E., Çakır, Z., Page, D., Hengesh, J. and Seitz, g. (2000), Paleoseismic trenching study across the Yalova segment of the North Anatolian fault, Hersek Peninsula, Turkey, in The 1999 Izmit and Düzce Earthquakes: Preliminary Results: 329-339.

Yalçıner, A.C., Alpar, B., Altınok, Y, Özbaya, İ and Imamurad, F. (2002): Tsunamis in the Sea of Marmara: Historical documents for the past, models for the future, Marine Geology Volume 190, Issues 1-2: 445-463.

Yaltırak C, Sakınç M, Aksu AE, Hiscott RN, Galleb B. and Ülgen UB (2002) Late Pleistocene uplift history along the southwestern Marmara Sea determined from raised coastal deposits and global sea-level variations. Mar Geol 190:283-305.

Zitter, TAC., Grall, C., Henry, P., Özeren, MS., Çağatay, MN., Şengör, AMC., Gasperini, L., Mercier de Lépinay, B. and Gélif, L. (2012). Distribution, morphology and triggers of submarine mass wasting in the Sea of Marmara, Marine Geology, Vol. 329-331: 58-74. 